\title{
Fasting, Fats, and Physics: Combining Ketogenic and Radiation Therapy against Cancer
}

\author{
Rainer Johannes Klement \\ Department of Radiotherapy and Radiation Oncology, Leopoldina Hospital Schweinfurt, Schweinfurt, Germany
}

\author{
Keywords \\ Chemotherapy · Differential stress resistance · Fasting . \\ Ketogenic diet $\cdot$ Radiotherapy
}

\section{Summary}

Radiotherapy (RT) is a mainstay in the treatment of solid tumors and works by physicochemical reactions inducing oxidative stress in cells. Because in practice the efficacy of RT is limited by its toxicity to normal tissues, any strategy that selectively increases the radiosensitivity of tumor cells or boosts the radioresistance of normal cells is a valuable adjunct to RT. In this review, I summarize preclinical and clinical data supporting the hypothesis that ketogenic therapy through fasting and/or ketogenic diets can be utilized as such an adjunct in order to improve the outcome after RT, in terms of both higher tumor control and lower normal-tissue complication probability. The first effect relates to the metabolic shift from glycolysis towards mitochondrial metabolism, which selectively increases reactive oxygen species (ROS) production and impairs adenoside triphosphate (ATP) production in tumor cells. The second effect is based on the differential stress resistance phenomenon describing the reprogramming of normal cells, but not tumor cells, from proliferation towards maintenance and stress resistance when glucose and growth factor levels are decreased and ketone body levels are elevated. Underlying both effects are metabolic differences between normal and tumor cells. Ketogenic therapy is a non-toxic and cost-effective complementary treatment option that exploits these differences and deserves further clinical investigation.

(C) 2017 S. Karger GmbH, Freiburg

\author{
Schlüsselwörter \\ Chemotherapie - Differenzielle Stressresistenz · Fasten · \\ Ketogene Diät · Strahlentherapie
}

\section{Zusammenfassung}

Die Strahlentherapie ist eine Hauptstütze in der Behandlung solider Tumoren und wirkt über physikalisch-chemische Reaktionen, die oxidativen Stress in Zellen erzeugen. Die Wirkung auf Tumorzellen wird durch die Toxizität für das mitbestrahlte gesunde Gewebe limitiert. Deshalb ist jede Behandlung, durch die eine selektive Sensibilisierung von Tumorzellen bzw. eine Stärkung normaler Zellen gegenüber ionisierender Strahlung erreicht wird, eine wertvolle Ergänzung der Strahlentherapie. In dieser Übersichtsarbeit fasse ich Daten aus vorklinischen und klinischen Studien zusammen, die für eine solche selektive Wirkung einer ketogenen Therapie durch Fasten und/oder eine ketogene Diät sprechen und eine Verbesserung der Tumorkontrollwahrscheinlichkeit bzw. eine Senkung der Wahrscheinlichkeit für eine Normalgewebeschädigung nahelegen. Erstere Wirkung hängt mit der metabolischen Umstellung von der Glykolyse zum mitochondrialen Stoffwechsel zusammen, was für Tumorzellen eine Erhöhung der freien Sauerstoffradikale und eine verminderte ATP-Generierung zur Folge hat. Der zweite Effekt beruht auf dem Phänomen der differenziellen Stressresistenz, das durch eine Verminderung von Wachstumsfaktoren und Glukose sowie eine Erhöhung der Ketonkörper vermittelt wird und gesunde Zellen, aber nicht Tumorzellen von Wachstum auf Stressresistenz umprogrammiert. Beide Effekte beruhen letztlich auf der metabolischen Verschiedenheit gesunder und maligner Zellen, die durch eine ketogene Therapie als Zusatz zur Strahlentherapie kostengünstig und vergleichsweise nebenwirkungsfrei ausgenutzt werden könnte und daher weitere klinische Erforschung verdient.

\section{KARGER

() 2017 S. Karger GmbH, Freiburg
Dr. Rainer Johannes Klement

Department of Radiotherapy and Radiation Oncology Leopoldina Hospital Schweinfurt

Robert-Koch-Straße 10, 97422 Schweinfurt, Germany rainer_klement@gmx.de 


\section{Introduction}

\section{Some Historical Remarks}

The incidence of cancer is increasing worldwide, placing a high burden not only on health care systems but also on the global society as a whole [1]. While much of this increase is attributed to an increasing life expectancy, many lines of evidence suggest that old age is not sufficient for cancer progression to a life-threatening disease; instead, most cancers, in particular the most common ones of epithelial origin, seem to develop under the influence of a perturbed metabolism associated with the modern lifestyle [2]. Obesity, chronic low-grade inflammation, and high blood glucose, insulin and insulin-like growth factor 1 (IGF-1) levels have been associated with a higher risk not only of developing but also of dying from various cancers $[2,3]$. We [4] and others [5-7] have argued that the deviation from our ancestral dietary patterns [8], most notably the strong increase of carbohydrate consumption, plays a significant role in this metabolic transition and tumorigenesis. Consistent with this are reports from the first half of the 20th century of a complete lack of or much fewer cancer cases among native societies compared to civilized white people [5, 9-13], despite many natives reaching an old age $[9,13]$. Notably, all these native societies seemed to rely on a high consumption of animal-based foods until these foods were replaced by mostly refined grains and sugar, upon which the cancer incidence rose sharply $[5,11]$. As Urquhart put it in 1935 [13]: 'Some associate [the absence of cancer among Eskimos and Indians] with the extraordinarily simple diet of the natives ... [which] is remarkable for its very high proportion of fat and its almost complete lack of carbohydrates. It consists almost entirely of fat and protein.'

Such diets of mostly fat and almost complete lack of (digestible) carbohydrate are referred to as ketogenic diets (KDs) because they promote ketogenesis, in this way mimicking the metabolic state of fasting. Already 22years prior to Urquhart's statement, Van Alstyne and Beebe [14] had established that feeding a carbohydratefree diet to rats had a significantly protective effect against transplantation of the Buffalo rat sarcoma. In the 1920's, Otto Warburg and coworkers provided a mechanistic link between carbohydrate metabolism and tumor growth by showing that tumor tissue in general consumes several-fold more glucose than normal tissue and excretes high amounts of lactate even under aerobic conditions, a fundamental difference to fast proliferating normal tissue in which respiration would minimize lactate production [15-17]. This phenomenon was first confirmed in vivo by Cori and Cori [18], by comparing blood samples from a tumor-bearing wing and a healthy wing in chickens and a forearm sarcoma with the healthy arm in 1 patient. It is nowadays termed the 'Warburg effect' and is utilized clinically for imaging and staging tumors via 2-deoxy$2-\left[{ }^{18} \mathrm{~F}\right]$ fluoro-D-glucose positron emission tomography (FDGPET) [19]. Based on Warburg's observations, in 1941/42, the Munich physician Wilhelm Brünings tested the antitumor effects of drastic blood glucose reduction via a KD combined with insulin injections in head-and-neck cancer patients [20, 21]. He reported remarkable results, which were, however, not reproduced by a dif- ferent group [22]. There are 2 other reports of cancer treatment using Brünings's method: The one from 1952, however, made no mention of the diet component of the treatment [23] and the one from 1957 reported some favorable results but utilized a calorierestricted low-carbohydrate diet of $124 \mathrm{~g}$ carbohydrate, $66 \mathrm{~g}$ fat, and $56 \mathrm{~g}$ protein per day, which did not induce ketosis [24]. Any reports mentioning a KD for cancer patients seemed to have vanished from the literature, until 1995, when Nebeling et al. [25] published 2 cases of malignant brain tumors in children that were successfully treated with a KD and standard therapy. To date, more than 24 reports have been published, in which more than 200 cancer patients were described to have been treated with a KD [26].

\section{Tumor Cell Metabolism and Radiotherapy}

The Warburg effect is sometimes confused with the Warburg hypothesis [27], proposed by Otto Warburg in 1956, stating that cancer is a disease of irreversibly damaged respiration [28]. The Warburg hypothesis has gained considerable experimental support, in particular in its re-formulation as the hypothesis that dysfunctional mitochondria are a frequent characteristic of cancer cells, forcing them into a dependence on substrate fermentation, in particular of glucose [29-31]. Newer data reveal that glycolysis not only serves as a compensatory pathway for adenoside triphosphate (ATP) production but also serves multiple purposes, among which the production of building blocks for cell proliferation and antioxidative substrates for protection against reactive oxygen species (ROS) are of high importance [32,33]. Consistently, experiments depriving cancer cells of glucose have associated cell death with both energy stress $[34,35]$ and oxidative stress [36-40]. Targeting this weakness of tumor cell metabolism through nutritional strategies has recently gained interest as a measure to support pro-oxidative therapies such as ionizing radiation (IR) or hyperbaric oxygen (HBO) [41-44]. The majority of newly diagnosed cancer patients will be confronted with radiotherapy (RT) at some point during their treatment [45]. Recent technical developments have made RT ever more precise, and hence more effective, but also safer with regard to the occurrence of side effects. Still, however, the doses that can be applied in a single RT fraction are limited by their toxicities to normal tissue. Therefore, any intervention that selectively inhibits the defense mechanisms of tumor cells and/or increases the resistance of normal cells to IR would be a highly valuable addition to this standard treatment. In this article, I summarize the evidence for using ketogenic therapy to improve the therapeutic window in RT, with the incorporation of newer findings that have been published since our first review on this topic [42].

\section{Ketogenic Therapy through Fasting and Ketogenic Diets}

I distinguish between dietary restriction, which is a general term describing any form of targeted restriction of either macronutrients or total energy intake and includes carbohydrate and protein restriction, and calorie restriction (CR), which defines diets re- 
stricting the total energy intake without inducing malnutrition. Prescribing $\mathrm{x} \%$ CR means that energy intake is restricted to (100 $\mathrm{x}) \%$ of that which would be consumed ad libitum, with $\mathrm{x}$ being typically in the range of 20-50. Fasting is the most extreme form of CR $(\mathrm{x}=100)$ and is usually limited to a maximum of 3 days, which I refer to as short-term fasting (STF). KDs are defined as isocaloric high-fat diets, in which fat usually accounts for $\gtrsim 75 \%$ of the energy intake. Because the adaptions to fasting are mainly driven by the absence of carbohydrates [46], KDs are fasting-mimicking diets, mainly by their elevation of the ketone bodies, $\beta$-hydroxybutyrate (BHB) and acetoacetate (AcAc) [47-49]. Ketogenic therapy is an umbrella term describing the application of nutritional strategies (CR, KDs, fasting, or exogenous ketone bodies) with the goal to induce systemic ketosis for therapeutic purposes [50]. Unfortunately, studies on CR rarely measure ketone body levels, but results from those that have done so reveal significant elevations of ketone body levels, at $\gtrsim 30 \% \mathrm{CR}$ in mice [51-53]. Mahoney et al. [51] have shown that an average of $40 \%$ CR over 3 weeks resulted in a $367 \%$ elevation of the BHB concentrations and a $41 \%$ drop in the glucose levels in mice, results that are comparable to very-low-calorie diets or STF in humans. Due to this translation, this review focusses on STF and KDs that have been shown to be feasible in their application to cancer patients in first pilot studies.

\section{The Physics and Biology of Radiotherapy against Cancer}

Modern-day RT is mainly delivered percutaneously using polyenergetic X-rays produced in 4-18-MV linear accelerators [54, 55]. Upon entering the body, the photons are attenuated through the 3 main interactions of the photoelectric effect, Compton scattering, and - starting at energies greater than $1,022 \mathrm{keV}$ - pair production. These processes ionize atoms and molecules, setting free electrons, which in turn can induce ionization and excitation events until they are completely absorbed. The initial ionization events occur within $10^{-16}-10^{-13} \mathrm{~s}$, which is called the physical phase $[54,56]$. In the subsequent physicochemical phase, the absorbed energy is distributed within and between molecules through thermodynamical energy transfer, producing free radicals (highly reactive molecules with an unpaired valence electron) and other reactive particles and molecules within about $10^{-13}-10^{-2} \mathrm{~s}$ after radiation exposure. The most common event is the radiolysis of cell water, in which different interactions of water with a photon or free electron yield free radicals $\left(\mathrm{H}^{\cdot},{ }^{\cdot} \mathrm{OH}\right)$, hydrated electrons (electrons surrounded by a shell of 5-7 water molecules), and other reactive compounds $\left(\mathrm{H}_{2}\right.$, $\mathrm{H}_{2} \mathrm{O}_{2}, \mathrm{OH}^{-}$) [54, 57]. The action of ionizing radiation is classified as direct or indirect, depending on whether the absorption of energy (ionization or excitation) occurs within the same molecule that is damaged or on surrounding molecules that diffuse to and react with the target molecule [58].

Warters and Hofer [59] and Warters et al. [60] provided evidence that the crucial target of RT is the nuclear DNA (nDNA) molecule, not the cytoplasm or the cell membrane. This nucleus- centered view still prevails today in textbooks [54-56]. Biophysical analyses reveal that initial ionization events from X-rays are not homogeneously distributed but occur along distinct tracks, with a potential to cluster within a few nanometers. In this case, the nDNA damage is associated with multiple damage sites within a few base pairs from both direct energy absorption and indirect modifications through ROS (mainly $\mathrm{OH}$ ) produced within the immediate surroundings that were able to reach the nDNA before being scavenged $[61,62]$. The indirect nDNA damage therefore depends on the amount of oxygen and anti-oxidants such as glutathione in the microenvironment, as discussed further below. In an aerated diploid cell, 1 Gy of X-irradiation produces $\gtrsim 10^{5}$ ionizations, $\gtrsim 1000 \mathrm{nDNA}$ base modifications, $\sim 1000$ single-strand breaks, and 25-40 double-strand breaks [56, 63]. nDNA damage triggers a highly complex DNA damage response involving the recruitment of certain proteins to damaged sites and the activation of checkpoint, DNA repair, and cell death pathways [56].

Ionization clusters are also predicted to occur within mitochondria [64], which seems to have much higher relevance for RT outcomes than realized in the past $[65,66]$. Mitochondrial DNA (mtDNA) is more vulnerable to ionizing radiation than $\mathrm{nDNA}$, due to a lack of histone protection and less efficient repair mechanisms $[67,68]$. Damage to mtDNA causes or augments mitochondrial dysfunction, increasing leakage from the electron transport chain, with long-lasting increases in mitochondrial reactive nitrogen species (mtRNS, formed from NO) and mitochondrial ROS (mtROS) formation, in particular of $\mathrm{O}_{2}{ }^{--}$(superoxide). Mitochondrial dysfunction triggers a retrograde stress response altering nuclear gene transcription [69]. According to Seyfried and Shelton [29], this mechanism is able to account for all the hallmarks of cancer and can be therapeutically targeted using CR and/or KDs. Leach et al. [70] proposed a mechanism by which IR-induced mtROS and mtRNS trigger mitochondrial $\mathrm{Ca}^{2+}$ release with subsequent uptake by adjacent mitochondria, which in turn undergo a transient permeability transition with mtROS and mtRNS production and $\mathrm{Ca}^{2+}$ release, in this way propagating the signal. A recent experiment using carbon ion and proton microbeams demonstrated that energy absorption within a mitochondrial cluster caused a near-instant $(<1 \mathrm{~s})$ and simultaneous depolarization of all the mitochondria belonging to the cluster and of connected mitochondria as far as $18 \mu \mathrm{m}$ away from the irradiated site [71]. The authors proposed changes in the membrane structure such as lipid peroxidation caused through a direct or indirect (ROS-mediated) action as possible causes of the depolarization. Along these lines, Kam and Banati [65] proposed the diffusion of excessively produced superoxide from damaged mitochondria as another damage propagation pathway that could ultimately reach the nucleus and induce 'mitochondrial superoxide-mediated nuclear damage'. All these mechanisms are consistent with data implying that the mitochondrial location of anti-oxidative enzymes is more cell protective than the cytosolic one, in particular in case of manganese superoxide dismutase (MnSOD) which dismutates superoxide to the less toxic hydrogen peroxide $\left(\mathrm{H}_{2} \mathrm{O}_{2}\right)$ [65]. According to Richardson and Harper [66], the mtROS and mtRNS produced through IR 


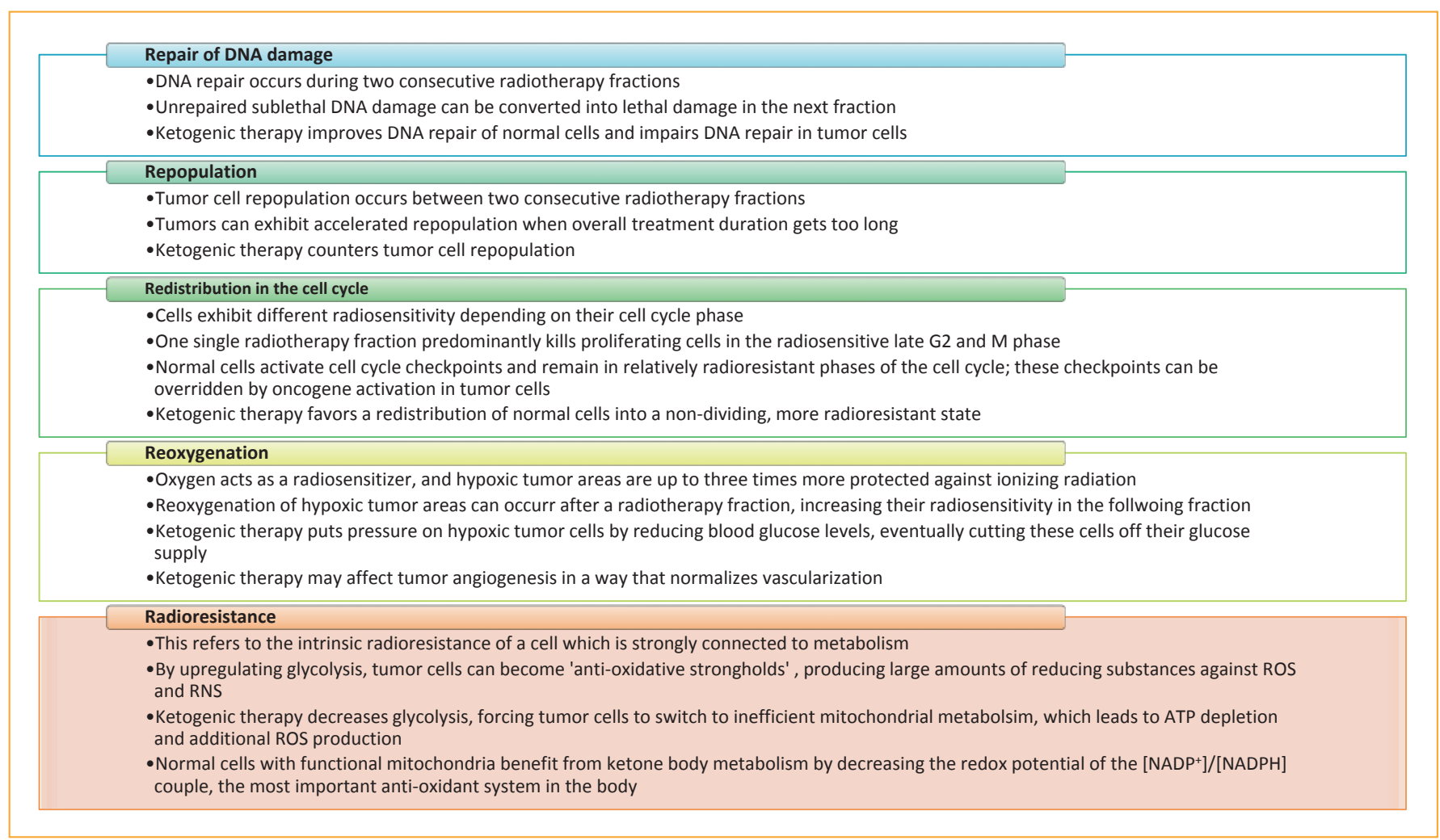

Fig. 1. The 5 R's of radiobiology and their modification through ketogenic therapy. These factors influence long-term tumor control and normal tissue reactions. For details see references $[42,44]$.

could fully account for the majority of nDNA damage and most of the observed RT effects.

Collectively, it seems that, while nDNA damage is the most important aspect of RT, this could be mainly a secondary effect of mtDNA damage and mtROS/mtRNS production. On the cellular level, both the mtDNA and the nDNA damage response can lead to a transient or permanent stop in the cell cycle, or induce programmed cell death, usually after a few or more cell divisions. On the tumor level, the outcome of RT will depend on 5 factors, classically known as the 5 R's of radiobiology, which determine whether long-term tumor control will be achieved or not (fig. 1). Evidence that each of these factors can be modified through ketogenic therapy has been reviewed by us recently $[42,44]$.

\section{Combining Ketogenic Metabolic Therapy with Radiotherapy to Enhance the Anti-Tumor Effects}

\section{Interfering with the Anti-Oxidative Defense Mechanism of \\ Tumor Cells}

As already indicated above, the amount of radical scavengers, additional radicals from mitochondrial metabolism and oxygen within the microenvironment of the DNA, all have an influence on the resulting DNA damage. In 1942, Wilhelm Brünings noted a sensitization of head-and-neck tumors to radium therapy when patients underwent his 'Entzuckerungsmethode' (de-glycation method) consisting of a KD combined with insulin injections in order to maximally lower the blood glucose levels [21]. On the other hand, modern PET imaging studies have confirmed that tumor areas with a high glycolytic metabolism are more radioresistant than those with a more oxidative metabolic phenotype $[72,73]$.

As already mentioned, a large body of evidence supports the notion that tumor cells frequently differ from their normal cell counterparts by dysfunctional mitochondria. The alterations include morphological abnormalities, lipid composition changes, and nDNA and mtDNA mutations encoding components of the respiratory chain complexes, resulting in respiratory insufficiency and increased production of $\mathrm{mtROS} / \mathrm{mtRNS}$ (reviewed in [29, 74-76]). The Warburg effect seems to help such cells in neutralizing the high intrinsic levels of ROS [43]. Accordingly, glucose withdrawal was shown to lead to mtROS-mediated cell death in tumor cells, but not in normal cells with intact mitochondria [36-40]. In contrast, high glucose concentrations in the tumor microenvironment help to scavenge ROS through increased production of anti-oxidative substrates such as lactate and glutathione through glycolytic pathways, which would also aid against IR or chemotherapy-associated ROS [33, 77]. Nicotinamide adenine dinucleotide phosphate (NADPH) produced during the oxidation of glucose-6-phosphate in the pentose phosphate pathway maintains glutathione, the most important scavenger of $\mathrm{H}_{2} \mathrm{O}_{2}$ and other peroxides, in the reduced state [78]. It has been shown that KDs and STF are able to downregulate this anti-oxidative defense mechanism in tumor cells and sensitize them to additional therapy-induced oxidative stress (reviewed in $[42,43])$. In a case study of cancer patients, those who 
kept a strict $\mathrm{KD}$ showed reduced levels of the tumor marker TKTL-1 (transketolase-like 1), which is supposed to be associated with the pentose phosphate pathway [79]. Studies using FDG-PET imaging $[25,80]$ or microdialysis measurements [81] have shown that a $\mathrm{KD}$ can downregulate the glycolytic tumor metabolism in some patients. A decrease in tumor lactate production has also been observed in mice kept on a $\mathrm{KD}[82,83]$ and in cultured cancer cells treated with ketone bodies $[84,85]$ or fasting-mimicking conditions $[86,87]$. The decreased tumor lactate concentrations after a few days on a KD in head-and-neck cancer patients measured by Schroeder et al. [81] are of particular interest, as tumor lactate concentrations have been directly linked to radioresistance in a variety of xenografted head-and-neck tumors that were irradiated using a clinically relevant schedule of 30 fractions over 6 weeks [88, 89].

Besides glycolysis, another adaption to high mtROS production frequently occurring in cancer cells is uncoupling of oxidative phosphorylation and ATP production through overexpression of uncoupling protein 2 (UCP2), which is also associated with increased resistance against chemotherapy and RT. Uncoupling allows protons to leak from the intermembrane space back into the matrix, decreases the mitochondrial membrane potential and thus reduces the emission of mtROS [90]. However, this comes at the expense of inefficient ATP generation. Fine et al. [91] have targeted this protective mechanism through administration of AcAc, which led to ATP depletion and growth inhibition. In their explanation, increased uncoupling or mitochondrial dysfunction in general would prohibit mitochondrial production of sufficient ATP to compensate for the reduced glycolytic ATP production that follows from the Randle cycle-like inhibitory effects of free fatty acids and ketone bodies on glycolysis.

\section{Increasing ROS Production in Tumor Cells}

Under non-hypoxic conditions, a shift from glycolysis towards (inefficient) mitochondrial metabolism through KDs and fasting would selectively increase the mtROS levels in tumor cells by increasing electron leakage through the electron transport chain. In a murine CT26 colon cancer model, STF decreased both glycolysis and glutaminolysis while shifting metabolism towards the mitochondria, which resulted in enhanced mtROS production and ATP depletion [86]. Marini et al. [87] confirmed these findings, showing that STF in vitro enhanced the oxygen consumption rate and increased the complex I and IV activity in murine CT26 colon and $4 \mathrm{~T} 1$ breast cancer cells, leading to a subsequent boost in mtROS production. Similarly, Lee et al. [92] measured increased oxidative stress under in vitro fasting conditions in $4 \mathrm{~T} 1$ cells, which they associated with the increased superoxide levels and the synergistic responses they observed when allografted tumors were treated with combined fasting and cyclophosphamide. Synergistic effects between fasting and chemotherapy were also observed in murine B16 melanoma and GL26 glioma allografts, human breast cancer and ovarian cancer xenografts (all treated with doxorubicin [92]), pancreatic cancer xenografts treated with gemcitabine [93], CT26 colorectal allografts treated with oxaliplatin [86], and murine fibrosarcoma allografts treated with mitoxantrone or oxaliplatin [94] (table 1). Furthermore, Morscher et al. [95] revealed synergistic effects between a KD and metronomic chemotherapy with cyclophosphamide in 2 neuroblastoma xenograft models. However, some other studies found no synergistic cytotoxic effects between fasting and chemotherapy (table 1). It is possible that ATP production in these tumors could be maintained at sufficiently high levels to enable efficient DNA repair [96]. Collectively, considering that all these chemotherapy regimens provoke oxidative stress in the tumors to varying degrees [97], these data support the hypothesis that KDs and STF are able to impair the anti-oxidative defense or further increase the ROS levels in several tumor cell lines, which sensitizes them to treatment by chemotherapy and RT.

\section{Synergistic Effects of Adding a KD to RT}

In contrast to some of the chemotherapy studies, thus far, all studies adding fasting or a KD to RT have indicated synergistic effects (table 2). In a murine GL26 glioma model, fasting for $48 \mathrm{~h}$ prior to each of 2 fractions delivering 5 and 2.5 Gy IR retarded tumor growth and prolonged survival of the treated mice more than IR or fasting alone [98]. Using the same murine glioma cells, Abdelwahab et al. [99] described more than additive effects when a KD was combined with $2 \times 2$ Gy RT, apparently curing most of the irradiated mice completely. Paradoxically, however, the ROS levels were decreased in tumors of mice fed with the KD.

Allen et al. [100] investigated the combination of a KD with IR against lung cancer xenografts using both conventionally fractionated $(34 \times 1.8 \mathrm{~Gy})$ and hypofractionated $(2 \times 6 \mathrm{~Gy})$ schedules. In both cases, adding the KD to RT achieved the greatest efficacy regarding tumor growth delay and mouse survival. In an additional experiment of irradiating with $6 \times 2$ Gy for 3 times per week, the efficacy could be further enhanced by combining the KD and IR with carboplatin administration. Tumor samples harvested from mice on the KD at the end of the hypofractionation experiment exhibited significantly higher levels of protein modifications with the lipid peroxidation marker 4-hydroxy-2-nonenal (4HNE), consistent with increased $\mathrm{KD}$-mediated oxidative stress in tumor cells [100]. Similar results were obtained using a pancreatic cancer xenograft model treated with $6 \times 2$ Gy [101]. In 2 clinical trials, the same working group had measured increases in plasma protein carbonyl content in lung and pancreatic cancer patients who adhered to a strict KD while receiving chemo-RT [101]. However, the small sample size $(\mathrm{n}=4)$ and the lack of a control group did not allow any conclusion as to whether the KD contributed to this increase of oxidative protein damage or whether it was solely due to the chemo-RT.

Finally, 2 studies investigating the combination of $30 \% \mathrm{CR}$ and IR in triple-negative breast cancer models have revealed synergistic anti-tumor effects that were related to a downregulation of the IGF-1 receptor (IGF-1R) and its downstream targets Akt and phosphoinositide 3-kinase (PI3K) in both primary tumors and metastases $[102,103]$. Although ketone bodies were not measured, these findings suggest an intriguing role for ketogenic therapy as a targeted therapy against the IGF-1R pathway in order to sensitize tumor cells against IR. IGF-1R overexpression in tumor cells is as- 


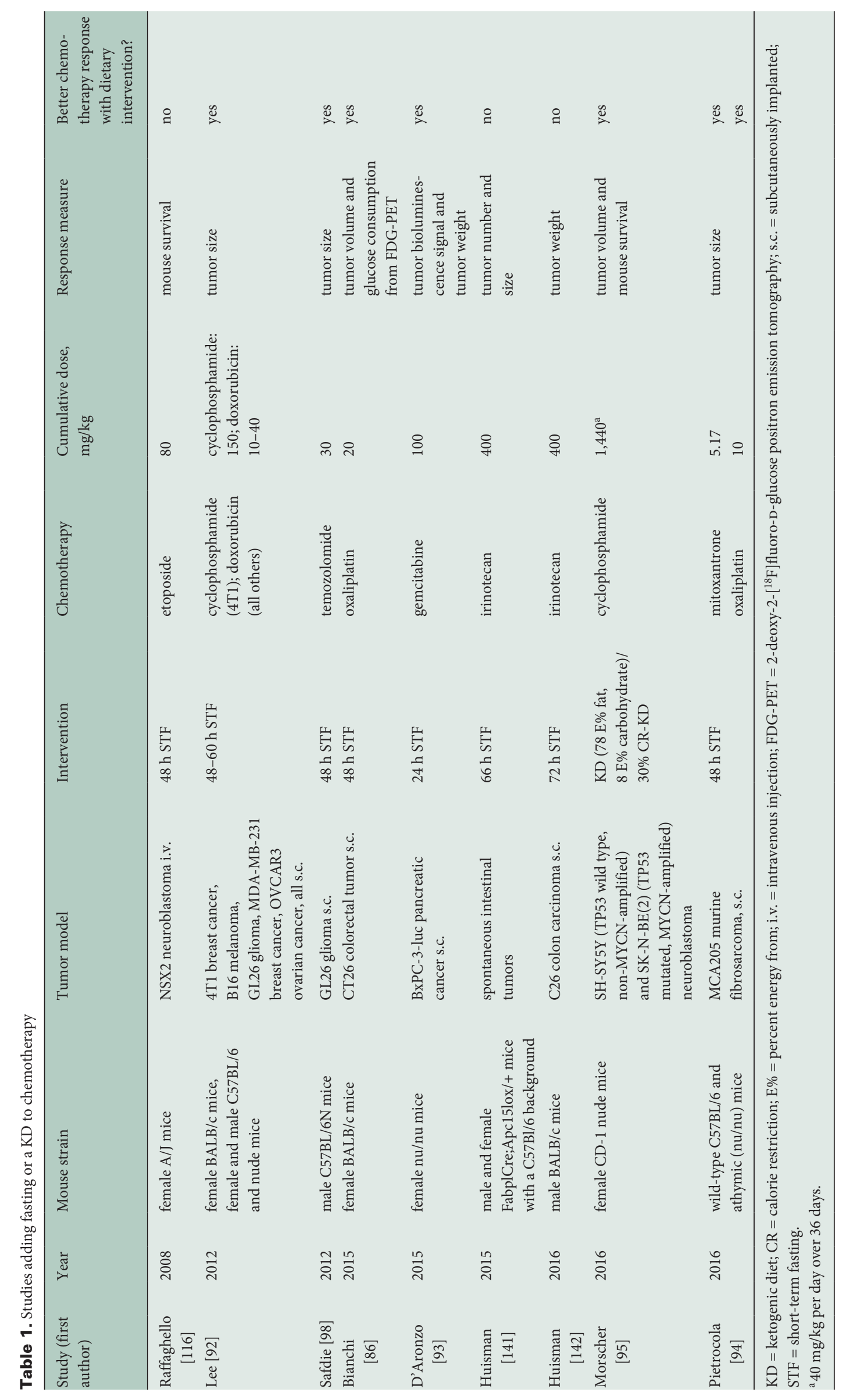


Table 2. Studies combining ketogenic metabolic therapy with RT

\begin{tabular}{|c|c|c|c|c|c|c|c|c|}
\hline $\begin{array}{l}\text { Study } \\
\text { (first author) }\end{array}$ & Year & Mouse strain & $\begin{array}{l}\text { Tumor } \\
\text { model }\end{array}$ & Intervention $^{\mathrm{a}}$ & Fractionation & $\begin{array}{l}\text { RT duration, } \\
\text { days }\end{array}$ & $\begin{array}{l}\text { Response } \\
\text { measure }\end{array}$ & $\begin{array}{l}\text { Better RT } \\
\text { response with } \\
\text { dietary } \\
\text { intervention? }\end{array}$ \\
\hline $\begin{array}{l}\text { Abdelwahab } \\
\text { [99] }\end{array}$ & 2012 & albino C57BL/6 & $\begin{array}{l}\text { GL261-luc2 } \\
\text { glioma } \\
\text { intracranial }\end{array}$ & $4: 1 \mathrm{KD}$ & $2 \times 4$ Gy & 2 & $\begin{array}{l}\text { tumor } \\
\text { bioluminescence } \\
\text { signal and } \\
\text { mouse survival }\end{array}$ & yes \\
\hline Safdie [98] & 2012 & male C57BL/6N & $\begin{array}{l}\text { GL26 glioma } \\
\text { s.c. }\end{array}$ & $48 \mathrm{~h} \mathrm{STF}$ & $1 \times 5+1 \times 2.5 \mathrm{~Gy}$ & 7 & tumor size & yes \\
\hline \multirow[t]{3}{*}{ Allen [100] } & 2013 & female & H292 lung & $4: 1 \mathrm{KD}$ & $6 \times 2 \mathrm{~Gy}$ & 10 & tumor volume & yes \\
\hline & & athymic-nu/nu & cancer s.c. & $4: 1 \mathrm{KD}$ & $34 \times 1.8 \mathrm{~Gy}$ & 77 & and mouse & yes \\
\hline & & & $\begin{array}{l}\text { H292 and } \\
\text { A549 s.c. }\end{array}$ & $4: 1 \mathrm{KD}$ & $2 \times 6 \mathrm{~Gy}$ & 2 & survival & yes \\
\hline \multirow[t]{2}{*}{ Saleh [102] } & 2013 & female BALB/c & $\begin{array}{l}\text { 67NR breast } \\
\text { cancer o.i. }\end{array}$ & $\begin{array}{l}\text { alternate day } \\
\text { fasting }\end{array}$ & $1 \times 6 \mathrm{~Gy}$ & 1 & tumor size & yes \\
\hline & & & $\begin{array}{l}4 \mathrm{~T} 1 \text { breast } \\
\text { cancer o.i. }\end{array}$ & $\begin{array}{l}30 \% \mathrm{CR} / \text { alternate } \\
\text { day fasting }\end{array}$ & $1 \times 8 \mathrm{~Gy}$ & & & \\
\hline Simone [103] & 2016 & female BALB/c & $\begin{array}{l}4 \mathrm{~T} 1 \text { breast } \\
\text { cancer o.i. }\end{array}$ & $30 \% \mathrm{CR}$ & $1 \times 8 \mathrm{~Gy}$ & 1 & $\begin{array}{l}\text { primary tumor } \\
\text { volume, number } \\
\text { of visible lung } \\
\text { metastases }\end{array}$ & yes \\
\hline Zahra [101] & 2017 & $\begin{array}{l}\text { female } \\
\text { athymic-nu/nu }\end{array}$ & $\begin{array}{l}\text { MIA PaCa-2 } \\
\text { pancreatic } \\
\text { cancer s.c. }\end{array}$ & $4: 1 \mathrm{KD}$ & $6 \times 2 \mathrm{~Gy}$ & 10 & $\begin{array}{l}\text { tumor volume } \\
\text { and mouse } \\
\text { survival }\end{array}$ & yes \\
\hline
\end{tabular}

${ }^{a}$ The ketogenic ratio (e.g. 4:1) gives the weight ratio between fat and carbohydrates + protein.

$\mathrm{RT}=$ radiotherapy; o.i. = orthotopically implanted; s.c. = subcutaneously implanted; $\mathrm{KD}=$ ketogenic diet; $\mathrm{STF}=$ short-term fasting; $\mathrm{CR}=$ calorie restriction.

sociated with high radioresistance due to the IGF-1R being involved in ATM-mediated DNA double-strand break repair (ATM = ataxia-telangiectasia mutated) [104].

\section{Influence on the Oxygen Effect and Tumor Cell DNA Repair}

The oxygen effect describes the enhancement of RT efficacy with increasing oxygen concentrations and is one of the main reasons why RT is applied in a fractionated scheme in order to utilize re-oxygenation of hypoxic tumor areas between RT fractions. For example, there is evidence that single-fraction stereotactic RT lacks a dose-response relationship and achieves lower tumor control rates than 3 or more fractions even if the same 'biologically effective doses' are applied $[105,106]$, which is consistent with a detrimental effect of missing re-oxygenation [107]. Oxygen is required for the production of superoxide from cell water radiolysis products, which greatly enhances the toxicity of IR [57]. Therefore, HBO before a RT session can be used to sensitize hypoxic tumor cells to IR, resulting in improved local control rates and overall survival $[108,109]$. While $\mathrm{HBO}$ alone is of limited clinical efficacy, the D'Agostino lab has shown that HBO therapy increased ROS production and inhibited the growth of highly aggressive VM-M3 mouse tumor cells. Feeding mice a KD and/or exogenous ketones thereby enhanced its efficacy in vivo $[41,110]$. This would support the use of both ketogenic therapy and $\mathrm{HBO}$ prior to an RT session as a complementary treatment approach. A recent case report of a poly-metastasized breast cancer patient in which a combination of
$\mathrm{HBO}, \mathrm{KD}, \mathrm{STF}$, glucose deprivation, hyperthermia and chemotherapy was used over 6 months reported a complete clinical, radiological, and pathological response and provides a proof-of-principle example for such integrative treatment concepts [111].

Recently, Richardson and Harper [66] proposed a 2-component model for the oxygen effect. In their explanation, as oxygen levels rise, damage from increasing levels of mtROS constitutes the main component which is more and more counteracted by more efficient DNA repair due to increasing ATP production. This model, however, assumes efficient oxygen-dependent ATP production and would not apply to those tumor cells that are unable to compensate for a loss of glycolytic ATP if forced to use mitochondrial metabolism. The failure to compensate for glycolytic ATP production would have severe consequences in terms of impaired DNA repair capacity. In this case, the overall oxygen enhancement of RT-induced damage against these tumor cells would be higher than predicted. Consistent with this, Bhatt et al. [112] have shown that glycolysis inhibition in cells with inefficient respiratory function significantly decreased the DNA double-strand break repair kinetics and radioresistance compared to those cells that were able to compensate for inefficient oxidative phosphorylation by maintaining high levels of glycolytic ATP production.

A frequent cause of inefficient oxidative phosphorylation and enhanced glycolysis in tumors cells are loss-of-function mutations of the tumor suppressor p53 [113]. A study utilizing a MYCNdriven neuroblastoma model revealed that p53 loss-of-function 
Fig. 2. Impact of ketogenic therapy on tumor cells and normal cells during irradiation. IR leads to the formation of ROS, mainly from radiolysis of cell water. ROS are produced in the vicinity of DNA and in mitochondria; the latter (in particular $\mathrm{H}_{2} \mathrm{O}_{2}$ ) are able to diffuse to nDNA and do damage. Tumor cells (left panel) typically exhibit higher intrinsic ROS levels than normal cells, due to mitochondrial dysfunction which

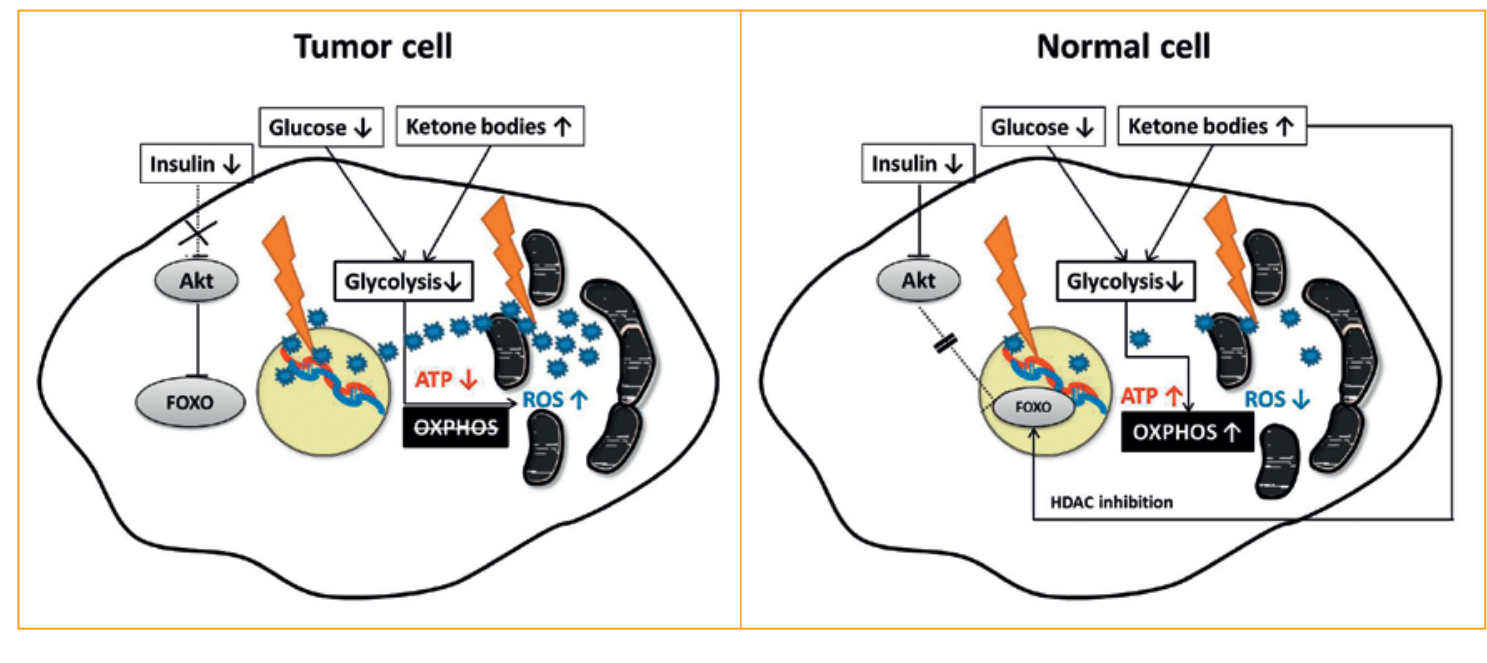

makes them dependent on glycolysis for anti-oxidant production. An elevation of ketone body levels and a decrease in blood glucose levels inhibit glycolysis, deplete ATP and increase ROS production in tumor cells. This is in contrast to normal cells (right panel) which are able to efficiently burn fatty acids and ketone bodies in mitochondria, which also optimizes the glutathione pool for $\mathrm{H}_{2} \mathrm{O}_{2}$ scavenging. The reduction of insulin (and IGF-1 in case of fasting) levels inhibits Akt signaling in normal cells, allowing FOXO transcription factors to translocate to the nucleus and promote DNA repair and stress resistance. HDAC inhibition through $\beta$-hydroxybutyrate also promotes FOXO3a, MnSOD, and catalase transcription. This stress resistance program does not run in tumor cells with oncogene gain-of-function (e.g., IGF-1R, PI3K) or tumor suppressor loss-of-function (e.g., p53, PTEN) mutations, which result in an activation of the PI3K-Akt and other proliferation pathways and lead to inactivation of FOXOs in the cytosol [118].

mutations confer high resistance against IR by reprogramming glutathione-associated metabolism and increasing the glutathione pool [114]. It is noteworthy that another $M Y C N$-amplified neuroblastoma model derived from SK-N-BE(2) cells was found to be extremely sensitive to metronomic cyclophosphamide, which had anti-angiogenic effects especially when combined with a KD [95]. It is also noteworthy that, in autophagy-competent cells, various forms of mutant but not wild-type p53 were degradable through deacetylation-induced autophagy triggered by glucose restriction in vitro and a low carbohydrate diet in vivo; depletion of mutant p53 subsequently induced autophagy-mediated cell death [115]. These findings support the application of ketogenic therapy along with RT against p53-mutated tumor cells.

\section{Protection of Normal Cells during Radiotherapy}

In 2008, Raffaghello et al. [116] introduced the term 'differential stress resistance' to describe the protective effects of STF on normal but not tumor cells against high-dose chemotherapy. Mechanistically this was shown to occur, in part, through downregulation of the Ras-Raf-MAP kinase (MAPK) und Akt-mammalian target of rapamycin (mTOR) signaling pathways $[116,117]$. The fastinginduced reduction of growth factors such as glucose, insulin, and IGF-1 inhibits Akt-mTOR signaling, promotes adipose tissue free fatty acid release and hepatic ketogenesis and globally activates a stress resistance program involving activation of adenosine monophosphate-activated protein kinase (AMPK), peroxisome proliferator-activated receptors (PPARs) and forkhead box class $\mathrm{O}$ (FOXO) transcription factors (reviewed in [118-120]). PPARs are 'the nuclear transcription factors of fat and fasting' [119] which are activated by a number of fatty acids and certain eicosanoids [121]; in target tissues, they promote numerous metabolic actions, but also anti-inflammatory effects $[119,121]$. FOXOs could be termed 'survival transcription factors' because they, among others, promote the transcription of a number of cell cycle arrest and anti-oxidant genes [122]. FOXOs are negatively regulated by phosphorylation through Akt downstream of the insulin receptor and IGF-1R, which prevents their translocation into the nucleus or translocates them from the nucleus into the cytosol, respectively, where they can get degraded by MDM2-induced polyubiquitylation (MDM2 = murine double minute 2). In contrast, phosphorylation by AMPK activates FOXOs without directly regulating their localization [122]. It was recently shown in vitro that BHB increases AMPK phosphorylation and FOXO3a-mediated expression of catalase and MnSOD [123]. Other data has revealed that BHB increases FOXO3a transcription by altering the chromatin structure at the FOXO3a promoter on nDNA through class I histone deacetylase (HDAC) inhibition [124], providing another mechanism for the upregulation of MnSOD and catalase (fig. 2). Accordingly, incubation of cardiomyocytes with $\mathrm{BHB}$ increased FOXO3a, MnSOD, and catalase expression and protected against $\mathrm{H}_{2} \mathrm{O}_{2}$ toxicity [125]. This supports the hypothesis that ketosis could be used in addition to modern RT techniques such as deep inspiration breath hold [126] to further reduce the risk of late cardiac toxicities from RT involving exposure of the heart. Opposite effects on tumor cells were recently described, showing that BHB added to mouse and human glioma cells in vitro inhibited HDAC activity in a dose-dependent manner, which impaired the DNA damage repair in the tumor cells [127].

Another anti-oxidative property of ketone bodies derives from their catabolism in the tricarboxylic acid (TCA) cycle, which yields 
NADPH produced during the conversion of isocitrate to a-ketoglutarate catalyzed by the action of the $\mathrm{NADP}^{+}$-dependent isocitrate dehydrogenases 1 (in the cytosol) and 2 (in the mitochondria). This NADPH donates electrons for reduction of glutathione in the same way as does NADPH stemming from the pentose phosphate pathway (reviewed in [128]). Finally, BHB in physiological concentrations achieved during STF or a KD has been shown to exert an anti-inflammatory action, in part through inhibiting the NOD-like receptor protein 3 (NLRP3) inflammasome (reviewed in [129]).

To summarize, the combined action of low insulin signaling and elevated BHB levels achieved by STF or a KD exerts anti-inflammatory and anti-oxidative effects in normal cells. The same would not apply to tumor cells with constitutive activation of oncogenes or loss of function of tumor suppressors that are involved in the stress resistance program [118]. The result is a differential stress resistance between normal and tumor cells that could be exploited by using ketogenic interventions during chemotherapy and/or RT (fig. 2). All of the preclinical studies summarized in table 1 have confirmed a reduction of side effects from a variety of chemotherapeutic drugs without interfering with, or even boosting, their anti-tumor effects. To date, 3 small studies in humans have also found evidence of a protective effect of STF against chemotherapy-related toxicity [130-132]. These studies and their relevance for patients receiving chemotherapy have been discussed in detail elsewhere [133-136] and will only briefly be reviewed here. The first study, by Safdie et al. [130], was a case study of 10 patients who voluntarily fasted for $48-140 \mathrm{~h}$ prior to and 5-56 h after each of an average of 4 chemotherapy cycles. In 6 patients who partly had fasted and partly had not, side effects were reduced during those cycles in which chemotherapy had been combined with fasting, in particular fatigue and gastrointestinal problems. The second study, by deGroot et al. [131], was a randomized controlled trial in 13 human epidermal growth factor receptor 2 (HER2)-negative stage II and III breast cancer patients who were treated with 6 cycles of combined docetaxel, doxorubicin, and cyclophosphamide. The intervention group who fasted for $24 \mathrm{~h}$ prior up to $24 \mathrm{~h}$ after chemotherapy administration experienced a significant reduction in IGF-1 levels and lower insulin levels than the control group and exhibited signs of less DNA damage or more efficient DNA double-strand break repair in peripheral blood mononuclear cells [134]. The third study was a dose escalation study in a heterogeneous sample of 20 cancer patients who underwent $2 \mathrm{cy}$ cles of platinum-based chemotherapy in combination with fasting [132]. There was no control group, but the results indicated an inverse dose-response relationship between the fasting duration and the amount of DNA damage in peripheral blood mononuclear cells as well as the chemotherapy-induced myelosuppression [136]. Importantly, all 3 studies have shown that STF was feasible and resulted in only minor (grade 1 and 2) side effects.

An important role for ketone body-mediated protection was obtained from the study by Dorff et al. [132] in which longer fasting duration prior to chemotherapy appeared more protective, yet only $\mathrm{BHB}$, but not insulin, IGF-1 or glucose, were significantly different between 24 and $48 \mathrm{~h}$ of fasting prior to chemotherapy. This supports the hypothesis that KDs might be used as fasting-mimicking diets to reduce side effects from oxidative stress during prolonged treatment situations such as during several weeks of RT. Alternatively (or additionally) STF could be considered for patients receiving weekly chemotherapy during RT or for patients undergoing a few fractions of high-dose stereotactic RT. These and other possibilities of combining ketogenic therapy with different RT schedules should be tested in future preclinical and clinical studies.

Finally, it is important to note that the human STF studies have failed to reproduce the reductions in insulin and glucose levels seen in the mouse studies because corticosteroids were routinely administrated during chemotherapy $[134,136]$. This could have prevented some further reductions in side effects or blunted the effect sizes. More alarming are findings that corticosteroid use prior to RT was associated with significantly shorter overall and progression-free survival in 3 large cohorts of glioblastoma patients [137]. This was linked to a corticosteroid-induced redistribution of tumor cells from the relatively radiosensitive G2/M phase to the relatively radioresistant G1 phase, with maintenance of cell viability. Additionally, the corticosteroid-induced elevations of blood glucose levels would provide a radioprotective environment. We have argued that this could be countered with ketogenic therapy [138]. The proof of principle was provided by Champ et al. [139] who showed that consumption of a KD during RT lowered the blood glucose levels in glioblastoma patients even under concurrent corticosteroid treatment.

\section{Conclusions}

The preclinical data and mechanistic insights reviewed here support the notion that ketogenic therapy could improve the outcome after RT, both in terms of higher tumor control and lower normal-tissue complication probability. The first effect relates to the metabolic shift from glycolysis towards mitochondrial metabolism, which selectively increases ROS production and impairs ATP production in tumor cells. The second effect is based on the differential stress resistance phenomenon that is achieved when glucose and growth factors are reduced and ketone bodies are elevated, which causes normal cells to switch to a cellular maintenance and stress resistance program. Underlying both effects are the metabolic differences between normal and tumor cells that have been reviewed here and elsewhere $[42,43,118,140]$. First clinical studies indicate that a differential stress resistance can be induced by STF in humans; however, it has not been studied yet whether such as resistance could be mimicked by KDs and in this way be utilized for a longer course of RT. The large variety of RT and chemotherapy schedules employed in modern cancer treatment opens up a large number of possible ketogenic interventions, ranging from STF over KDs to the administration of exogenous ketone bodies. Ultimately, patient preferences and patient-related factors such as body composition will determine which form of ketogenic intervention can be considered. 


\section{Acknowledgement}

I thank Prof. Harald Walach for the kind invitation to write this review.

\section{Disclosure Statement}

The author declares that he has no conflicts of interest to disclose. No funding was received for writing this article.

\section{References}

1 Global Burden of Disease Cancer Collaboration, Fitzmaurice C, Allen C, Barber RM, Barregard L, Bhutta $\mathrm{ZA}$, et al: Global, regional, and national cancer incidence, mortality, years of life lost, years lived with disability, and disability-adjusted life-years for 32 cancer groups, 1990 to 2015: a systematic analysis for the Global Burden of Disease Study. JAMA Oncol 2017;3. 524-548.

2 Holly JMP, Zeng L, Perks CM: Epithelial cancers in the post-genomic era: should we reconsider our lifestyle? Cancer Metastasis Rev 2013;32:673-705.

3 Gallagher EJ, LeRoith D: Obesity and diabetes: the increased risk of cancer and cancer-related mortality. Physiol Rev 2015;95:727-748.

4 Fine EJ, Champ CE, Feinman RD, Márquez S, Klement RJ: An evolutionary and mechanistic perspective on dietary carbohydrate restriction in cancer prevention. J Evol Health 2016;1:15.

5 Stefansson V: Cancer: Disease of Civilization? New York, Hill and Wang, 1960.

6 Lutz W: Leben ohne Brot. Die wissenschaftlichen Grundlagen der kohlenhydratarmen Ernährung, ed 16. Gräfelfing, Informed, 2004.

7 Carrera-Bastos P, Fontes-Villalba M, O'Keefe JH, Lindeberg S, Cordain L: The Western diet and lifestyle and diseases of civilization. Res Rep Clin Cardiol 2011; 2:15-35.

8 Cordain L, Eaton SB, Sebastian A, Mann N, Lindeberg $S$, Watkins BA, et al: Origins and evolution of the Western diet: health implications for the 21st century. Am J Clin Nutr 2005;81:341-354.

$\checkmark$ Levin I: Cancer among the American Indians and its bearing upon the ethnological distribution of the disease. Z Krebsforsch 1910;9:422-435.

10 Fouché FP: Freedom of negro races from cancer. $\mathrm{Br}$ Med J 1923;1:1116.

11 Price W: Nutrition and Physical Degeneration: A Comparison of Primitive and Modern Diets and Their Effects. Oxford, Benediction Classics, 2010.

12 Brown GM, Cronk LB, Boag TJ: The occurrence of cancer in an Eskimo. Cancer 1952;5:142-143.

13 Urquhart JA: The most northerly practice in Canada. 1935. CMAJ 1992;147:1193-1196.

14 Van Alstyne EVN, Beebe SP: Diet studies in transplantable tumors - I. The effect of non-carbohydrate diet upon the growth of transplantable sarcoma in rats. J Med Res 1913;29:217-232.

15 Minami S: Versuche an überlebendem Carcinomgewebe. Biochem Z 1923;142:334-350.

16 Warburg O, Posener K, Negelein E: Über den Stoffwechsel der Carcinomzelle. Biochem Z 1924;152:309-343.

17 Warburg O, Wind F, Negelein E: The metabolism of tumors in the body. J Gen Physiol 1927;8:519-530.

18 Cori CF, Cori GT: The carbohydrate metabolism of tumors. II. Changes in the sugar, lactic acid, and co-combining power of blood passing through a tumor. J Biol Chem 1925;65:397-405.

19 Bensinger SJ, Christofk HR: New aspects of the Warburg effect in cancer cell biology. Semin Cell Dev Biol 2012;23:352-361

20 Brünings W: Beiträge zum Krebsproblem. 1. Mitteilung: Ueber eine diätetisch-hormonale Beeinflussung des Krebses. MMW Munch Med Wochenschr 1941;88: 117-123.
21 Brünings W: Beiträge zum Krebsproblem. 2. Mitteilung: Klinische Anwendungen der diätetisch-hormonalen Krebsbeeinflussung ('Entzuckerungsmethode'). MMW Munch Med Wochenschr 1942;89:71-76.

22 Schulte G, Schütz H: Insulin in der Krebsbehandlung. MMW Munch Med Wochenschr 1942;89:648-650.

23 Reich F: Zur Insulinbehandlung der Kachexie bei Carcinom. Med Klin 1952;47:936-937.

24 Weiss J: Über Erfahrungen mit Insulin und kohlenhyd ratreduzierender Diät bei inkurablen Krebskranken. Med Klin 1957;52:1190-1191.

25 Nebeling L, Miraldi F, Shurin S, Lerner E: Effects of a ketogenic diet on tumor metabolism and nutritional status in pediatric oncology patients: two case reports. J Am Coll Nutr 1995;14:202-208.

26 Klement RJ: Beneficial effects of ketogenic diets for cancer patients: a realist review with focus on evidence and confirmation. Med Oncol 2017;34:132.

27 Gonder U: Article on ketogenic dietary regimes for cancer highly misleading. Med Oncol 2017;34:109.

28 Warburg O: On the origin of cancer cells. Science 1956; 123:309-314.

29 Seyfried TN, Shelton LM: Cancer as a metabolic disease. Nutr Metab (Lond) 2010;7:7.

30 Seyfried TN, Flores RE, Poff AM, D’Agostino DP: Cancer as a metabolic disease: implications for novel therapeutics. Carcinogenesis 2014;35:515-527.

31 Seyfried TN: Cancer as a mitochondrial metabolic disease. Front Cell Dev Biol 2015;3:43.

32 Gillies RJ, Robey I, Gatenby RA: Causes and consequences of increased glucose metabolism of cancers. Nucl Med 2008;49:24S-42S.

33 Sattler UG, Mueller-Klieser W: The anti-oxidant capacity of tumour glycolysis. Int J Radiat Biol 2009;85:963971.

34 Demetrakopoulos GE, Linn B, Amos H: Rapid loss of ATP by tumor cells deprived of glucose: contrast to normal cells. Biochem Biophys Res Commun 1978;82: 787-794.

35 Priebe A, Tan L, Wahl H, Kueck A, He G, Kwok R, et al: Glucose deprivation activates AMPK and induces cell death through modulation of Akt in ovarian cancer cells. Gynecol Oncol 2011;122:389-395.

36 Spitz DR, Sim JE, Ridnour LA, Galoforo SS, Lee YJ: Glucose deprivation-induced oxidative stress in human tumor cells. A fundamental defect in metabolism ? Ann N Y Acad Sci 2000;899:349-362.

37 Ahmad IM, Aykin-Burns N, Sim JE, Walsh SA, Higashikubo R, Buettner GR, et al: Mitochondrial $\mathrm{O}_{2}{ }^{-}$and $\mathrm{H}_{2} \mathrm{O}_{2}$ mediate glucose deprivation-induced stress in human cancer cells. J Biol Chem 2005;280:4254-4263.

38 Jelluma N, Yang X, Stokoe D, Evan GI, Dansen TB, Haas-Kogan DA: Glucose withdrawal induces oxidative stress followed by apoptosis in glioblastoma cells but not in normal human astrocytes. Mol Cancer Res 2006; 4:319-330.

39 Aykin-Burns N, Ahmad IM, Zhu Y, Oberley LW, Spitz DR: Increased levels of superoxide and $\mathrm{H}_{2} \mathrm{O}_{2}$ mediate the differential susceptibility of cancer cells versus normal cells to glucose deprivation. Biochem J 2009;418: 29-37.

40 Graham NA, Tahmasian M, Kohli B, Komisopoulou E, Zhu M, Vivanco I: Glucose deprivation activates a metabolic and signaling amplification loop leading to cell death. Mol Syst Biol 2012;8:589.
41 Poff AM, Ari C, Seyfried TN, D’Agostino DP: The ketogenic diet and hyperbaric oxygen therapy prolong survival in mice with systemic metastatic cancer. PLoS One 2013;8:e65522.

42 Klement RJ, Champ CE: Calories, carbohydrates, and cancer therapy with radiation: exploiting the five R's through dietary manipulation. Cancer Metastasis Rev 2014;33:217-229.

43 Allen BG, Bhatia SK, Anderson CM, Eichenberger-Gilmore JM, Sibenaller ZA, Mapuskar KA, et al: Ketogenic diets as an adjuvant cancer therapy: history and potential mechanism. Redox Biol 2014;2:963-970.

44 Klement RJ: The influence of ketogenic therapy on the 5 R's of radiobiology. Int J Radiat Biol 2017; DOI: 10.1080/09553002.2017.1380330.

45 Miller KD, Siegel RL, Lin CC, Mariotto AB, Kramer JL, Rowland JH, et al: Cancer treatment and survivorship statistics, 2016. CA Cancer J Clin 2016;66:271-289.

46 Klein S, Wolfe RR: Carbohydrate restriction regulates the adaptive response to fasting. Am J Physiol 1992; 262:E631-E636.

47 Klement RJ: Calorie or carbohydrate restriction? The ketogenic diet as another option for supportive cancer treatment. Oncologist 2013;18:1056.

48 Klement RJ: Mimicking caloric restriction: what about macronutrient manipulation? A response to Meynet and Ricci. Trends Mol Med 2014;20:471-472.

49 Klement RJ, Fink MK: Dietary and pharmacological modification of the insulin/IGF-1 system: exploiting the full repertoire against cancer. Oncogenesis 2016;5:e193.

50 Winter SF, Loebel F, Dietrich J: Role of ketogenic metabolic therapy in malignant glioma: a systematic review. Crit Rev Oncol Hematol 2017;112:41-58.

51 Mahoney LB, Denny CA, Seyfried TN: Calorie restriction in $\mathrm{C} 57 \mathrm{BL} / 6 \mathrm{~J}$ mice mimics therapeutic fasting in humans. Lipids Health Dis 2006;5:13.

52 Morscher RJ, Aminzadeh-Gohari S, Feichtinger RG, Mayr JA, Lang R, Neureiter D, et al: Inhibition of neuroblastoma tumor growth by ketogenic diet and/or calorie restriction in a CD1-nu mouse model. PLoS One 2015;10:e0129802.

53 Shelton LM, Huysentruyt LC, Mukherjee P, Seyfried $\mathrm{TN}$ : Calorie restriction as an anti-invasive therapy for malignant brain cancer in the VM mouse. ASN Neuro 2010;2:e00038.

54 Krieger H: Grundlagen der Strahlungsphysik und des Strahlenschutzes, ed 3. Wiesbaden, Vieweg + Teubner, 2009.

55 Marcu L, Bezak E, Allen BJ: Biomedical Physics in Radiotherapy for Cancer, ed 1. Collingwood, CSIRO Publishing, 2012.

56 Wouters BG, Begg A: Irradiation-induced damage and the DNA damage response; in Joiner MC, van der Kogel AJ (eds): Basic Clinical Radiobiology, ed 4. Boca Raton, CRC Press, 2009, pp 11-26.

57 Azzam EI, Jay-Gerin JP, Pain D: Ionizing radiation-induced metabolic oxidative stress and prolonged cell injury. Cancer Lett 2012;327:48-60.

58 Ward JF: The yield of DNA double-strand breaks produced intracellularly by ionizing radiation: a review. Int J Radiat Biol 1990;57:1141-1150. 
59 Warters RL, Hofer KG: Cells radionuclide toxicity in cultured mammalian cells. Elucidation of the primary site for radiation-induced division delay. Radiat Res 1977;69:348-358.

60 Warters RL, Hofer KG, Harris CR, Smith JM: Radionuclide toxicity in cultured mammalian cells: elucidation of the primary site of radiation damage. Curr Top Radiat Res Q 1978;12:389-407.

61 Ward JF: Some biochemical consequences of the spatial distribution of ionizing radiation-produced free radicals. Radiat Res 1981;86:185-195.

62 Goodhead DT: The initial physical damage produced by ionizing radiations. Int J Radiat Biol 1989;56:623-634.

63 Olive PL: The role of DNA single- and double-strand breaks in cell killing by ionizing radiation. Radiat Res 1998;150:S42-S51.

64 Kam WWY, McNamara AL, Lake V, Banos C, Davies JB, Kuncic Z, et al: Predicted ionisation in mitochondria and observed acute changes in the mitochondrial transcriptome after gamma irradiation: a Monte Carlo simulation and quantitative PCR study. Mitochondrion 2013;13:736-742

65 Kam WW-Y, Banati RB: Effects of ionizing radiation on mitochondria. Free Radic Biol Med 2013;65:607619.

66 Richardson RB, Harper M: Mitochondrial stress controls the radiosensitivity of the oxygen effect: implications for radiotherapy. Oncotarget 2016;7:2146921483.

67 Yakes FM, Van Houten B: Mitochondrial DNA damage is more extensive and persists longer than nuclear DNA damage in human cells following oxidative stress. Proc Natl Acad Sci USA 1997;94:514-519.

68 Larsen NB, Rasmussen M, Rasmussen LJ: Nuclear and mitochondrial DNA repair: similar pathways? Mitochondrion 2005;5:89-108.

69 Cannino G, Di Liegro CM, Rinaldi AM: Nuclear-mitochondrial interaction. Mitochondrion 2007;7:359-366.

70 Leach JK, Van Tuyle G, Lin P, Schmidt-Ullrich R, Mikkelsen RB: Ionizing radiation-induced, mitochondriadependent generation of reactive oxygen/nitrogen. Cancer Res 2001;61:3894-3901.

71 Walsh DWM, Siebenwirth C, Greubel C, Ilicic K, Reindl J, Girst S, et al: Live cell imaging of mitochondria following targeted irradiation in situ reveals rapid and highly localized loss of membrane potential. Sci Rep 2017;7:46684.

72 Choi NC, Fischman AJ, Niemierko A, Ryu JS, Lynch T, Wain J, et al: Dose-response relationship between probability of pathologic tumor control and glucose metabolic rate measured with FDG PET after preoperative chemoradiotherapy in locally advanced non-smallcell lung cancer. Int J Radiat Oncol 2002;54:1024-1035.

73 Sun A, Johansson S, Turesson I, Dau A, Sörensen J: Imaging tumor perfusion and oxidative metabolism in patients with head-and-neck cancer using $1-\left[{ }^{11} \mathrm{C}\right]$-acetate PET during radiotherapy: preliminary results. Int J Radiat Oncol Biol Phys 2012;82:554-560.

74 Seyfried TN: Cancer as a Metabolic Disease: On the Origin, Management, and Prevention of Cancer. New York, John Wiley \& Sons, 2012.

75 Verschoor ML, Ungard R, Harbottle A, Jakupciak JP, Parr RL, Singh G: Mitochondria and cancer: past, present, and future. Biomed Res Int 2013;2013:612369.

76 Gaude E, Frezza C: Defects in mitochondrial metabolism and cancer. Cancer Metab 2014;2:10.

77 Meijer TWH, Kaanders JHAM, Span PN, Bussink J: Targeting hypoxia, HIF-1, and tumor glucose metabolism to improve radiotherapy efficacy. Clin Cancer Res 2012;18:5585-5594.

78 Meister A: Selective modification of glutathione metabolism. Science 1983;220:472-477.
79 Jansen N, Walach H: The development of tumours under a ketogenic diet in association with the novel tumour marker TKTL1: a case series in general practice. Oncol Lett 2016;11:584-592.

80 Fine EJ, Segal-Isaacson CJ, Feinman RD, Herszkopf S, Romano MC, Tomuta N, et al: Targeting insulin inhibition as a metabolic therapy in advanced cancer: a pilot safety and feasibility dietary trial in 10 patients. Nutrition 2012;28:1028-1035.

81 Schroeder U, Himpe B, Pries R, Vonthein R, Nitsch S, Wollenberg B: Decline of lactate in tumor tissue after ketogenic diet: in vivo microdialysis study in patients with head and neck cancer. Nutr Cancer 2013;65:843849.

82 Husain Z, Huang Y, Seth P, Sukhatme VP: Tumor-derived lactate modifies antitumor immune response: effect on myeloid-derived suppressor cells and NK cells. J Immunol 2014;191:1486-1495.

83 Otto C, Klingelhöffer C, Biggermann L, Melkus G, Mörchel P, Jürgens C, et al: Analysis of the metabolism of ketone bodies and lactate by gastrointestinal tumor cells in vitro. Aktuel Ernahrungsmed 2014;39:51-59.

84 Shukla SK, Gebregiworgis T, Purohit V, Chaika NV, Gunda V, Radhakrishnan P, et al: Metabolic reprogramming induced by ketone bodies diminishes pancreatic cancer cachexia. Cancer Metab 2014;2:18.

85 Kadochi YUI, Mori S, Fujiwara-Tani R, Luo Y, Nishiguchi Y, Kishi S, et al: Remodeling of energy metabolism by a ketone body and medium-chain fatty acid suppressed the proliferation of CT26 mouse colon cancer cells. Oncol Lett 2017;14:673-680.

86 Bianchi G, Martella R, Ravera S, Marini C, Capitanio S, Orengo A, et al: Fasting induces anti-Warburg effect that increases respiration but reduces ATP-synthesis to promote apoptosis in colon cancer models. Oncotarget 2015;6:11806-11819.

87 Marini C, Bianchi G, Buschiazzo A, Ravera S, Martella $\mathrm{R}$, Bottoni $\mathrm{G}$, et al: Divergent targets of glycolysis and oxidative phosphorylation result in additive effects of metformin and starvation in colon and breast cancer. Sci Rep 2016;6:19569.

88 Quennet V, Yaromina A, Zips D, Rosner A, Walenta S, Baumann $\mathrm{M}$, et al: Tumor lactate content predicts for response to fractionated irradiation of human squamous cell carcinomas in nude mice. Radiother Oncol 2006;81:130-135.

89 Sattler UGA, Meyer SS, Quennet V, Hoerner C, Knoerzer H, Fabian C, et al: Glycolytic metabolism and tumour response to fractionated irradiation. Radiother Oncol 2010;94:102-109.

90 Mailloux RJ, Harper M-E: Uncoupling proteins and the control of mitochondrial reactive oxygen species production. Free Radic Biol Med 2011;51:1106-1115.

91 Fine EJ, Miller A, Quadros EV, Sequeira JM, Feinman $\mathrm{RD}$ : Acetoacetate reduces growth and ATP concentration in cancer cell lines which over-express uncoupling protein 2. Cancer Cell Int 2009;9:14.

92 Lee C, Raffaghello L, Brandhorst S, Safdie FM, Bianchi G, Martin-Montalvo A, et al: Fasting cycles retard growth of tumors and sensitize a range of cancer cell types to chemotherapy. Sci Transl Med 2012;4:124ra27.

93 D’Aronzo M, Vinciguerra M, Mazza T, Panebianco C, Saracino C, Pereira SP, et al: Fasting cycles potentiate the efficacy of gemcitabine treatment in in vitro and in vivo pancreatic cancer models. Oncotarget 2015;6: 18545-18557.

94 Pietrocola F, Pol J, Vacchelli E, Rao S, Enot DP, Ba racco $\mathrm{EE}$, et al: Caloric restriction mimetics enhance anticancer immunosurveillance. Cancer Cell 2016;30: $147-160$.

95 Morscher RJ, Aminzadeh-Gohari S, Hauser-Kronberger C, Feichtinger RG, Sperl W, Kofler B: Combination of metronomic cyclophosphamide and dietary intervention inhibits neuroblastoma growth in a CD1-nu mouse model. Oncotarget 2016;7:17060-17073.
6 Qin L, Fan M, Candas D, Jiang G, Papadopoulos S, Tian L, et al: CDK1 enhances mitochondrial bioenergetics for radiation-induced DNA repair. Cell Rep 2015;13:2056-2063.

97 Conklin KA: Chemotherapy-associated oxidative stress: impact on chemotherapeutic effectiveness. Integr Cancer Ther 2004;3:294-300.

98 Safdie F, Brandhorst S, Wei M, Wang W, Lee C, Hwang S, et al: Fasting enhances the response of glioma to chemo- and radiotherapy. PLoS One 2012; 7:e44603.

99 Abdelwahab MG, Fenton KE, Preul MC, Rho JM, Lynch A, Stafford P, et al: The ketogenic diet is an effective adjuvant to radiation therapy for the treatment of malignant glioma. PLoS One 2012;7:e36197.

100 Allen BG, Bhatia SK, Buatti JM, Brandt KE, Lindholm KE, Button AM, et al: Ketogenic diets enhance oxidative stress and radio-chemo-therapy responses in lung cancer xenografts. Clin Cancer Res 2013;19:39053913

101 Zahra A, Fath MA, Opat E, Mapuskar KA, Bhatia SK, $\mathrm{Ma}$ DC, et al: Consuming a ketogenic diet while receiving radiation and chemotherapy for locally advanced lung cancer and pancreatic cancer: the University of Iowa experience of two phase 1 clinical trials. Radiat Res 2017;187:743-754.

102 Saleh AD, Simone BA, Savage J, Sano Y, Jin L, Champ $\mathrm{C}$, et al: Caloric restriction augments radiation efficacy in breast cancer. Cell Cycle 2013;12:1955-1963.

103 Simone BA, Dan T, Palagani A, Jin L, Han SY, Wright $\mathrm{C}$, et al: Caloric restriction coupled with radiation decreases metastatic burden in triple negative breast cancer. Cell Cycle 2016;15:2265-2274.

104 Werner H, Sarfstein R, LeRoith D, Bruchim I: Insulinlike growth factor 1 signaling axis meets $\mathrm{p} 53$ genome protection pathways. Front Oncol 2016;6:159.

105 Guckenberger M, Klement RJ, Allgäuer M, Appold S, Dieckmann K, Ernst I, et al: Applicability of the linearquadratic formalism for modeling local tumor control probability in high dose per fraction stereotactic body radiotherapy for early stage non-small cell lung cancer. Radiother Oncol 2013;109:13-20.

106 Shuryak I, Carlson DJ, Brown JM, Brenner DJ: Highdose and fractionation effects in stereotactic radiation therapy: analysis of tumor control data from 2965 patients. Radiother Oncol 2015;115:327-334.

107 Lindblom E, Antonovic L, Dasu A, Lax I, Wersäll P, Toma-Dasu I: Treatment fractionation for stereotactic radiotherapy of lung tumours: a modelling study of the influence of chronic and acute hypoxia on tumour control probability. Radiat Oncol 2014;9:149.

108 Bennett MH, Feldmeier J, Smee R, Milross C: Hyperbaric oxygenation for tumour sensitisation to radiotherapy. Cochrane Database Syst Rev 2012;(4):CD005007.

109 Stępień K, Ostrowski RP, Matyja E: Hyperbaric oxygen as an adjunctive therapy in treatment of malignancies, including brain tumours. Med Oncol 2016;33:101.

110 Poff AM, Ward N, Seyfried TN, Arnold P, D’Agostino DP: Non-toxic metabolic management of metastatic cancer in VM mice: novel combination of ketogenic diet, ketone supplementation, and hyperbaric oxygen therapy. PLoS One 2015; 10:e0127407.

111 İyikesici MS, Slocum AK, Slocum A, Berkarda FB, Kalamian M, Seyfried TN: Efficacy of metabolically supported chemotherapy combined with ketogenic diet, hyperthermia, and hyperbaric oxygen therapy for stage IV triple-negative breast cancer. Cureus 2017;9:e1445.

112 Bhatt AN, Chauhan A, Khanna S, Rai Y, Singh S, Soni $\mathrm{R}$, et al: Transient elevation of glycolysis confers radioresistance by facilitating DNA repair in cells. BMC Cancer 2015;15:335.

113 Liang Y, Liu J, Feng Z: The regulation of cellular metabolism by tumor suppressor p53. Cell Biosci 2013;3:9. 
114 Yogev O, Barker K, Sikka A, Almeida GS, Hallsworth A, Smith LM, et al: p53 loss in MYC-driven neuroblastoma leads to metabolic adaptations supporting radioresistance. Cancer Res 2016;76:3025-3036.

115 Rodriguez OC, Choudhury S, Kolukula V, Vietsch EE, Catania J, Preet A, et al: Dietary downregulation of mutant p53 levels via glucose restriction: mechanisms and implications for tumor therapy. Cell Cycle 2012; 11:4436-4446.

116 Raffaghello L, Lee C, Safdie FM, Wei M, Madia F, Bianchi G, Longo VD: Starvation-dependent differential stress resistance protects normal but not cancer cells against high-dose chemotherapy. Proc Natl Acad Sci USA 2008; 105:8215-8220.

117 Lee C, Safdie FM, Raffaghello L, Wei M, Madia F, Parrella E, et al: Reduced levels of IGF-I mediate differential protection of normal and cancer cells in response to fasting and improve chemotherapeutic index. Cancer Res 2010;70:1564-1572.

118 Lee C, Longo VD: Fasting vs dietary restriction in cellular protection and cancer treatment: from model organisms to patients. Oncogene 2011;30:3305-3316.

119 Kurtak KA: Dietary and nutritional manipulation of the nuclear transcription factors peroxisome proliferator-activated receptor and sterol regulatory elementbinding proteins as a tool for reversing the primary diseases of premature death and delaying aging. Rejuvenation Res 2014;17:140-144.

120 Kopeina GS, Senichkin VV, Zhivotovsky B: Caloric restriction - a promising anti-cancer approach: from molecular mechanisms to clinical trials. Biochim Biophys Acta 2017;1867:29-41.

121 Cullingford TE: The ketogenic diet; fatty acids, fatty acid-activated receptors and neurological disorders. Prostaglandins Leukot Essent Fatty Acids 2004;70: 253-264.
122 Eijkelenboom A, Burgering BMT: FOXOs: signalling integrators for homeostasis maintenance. Nat Rev Mol Cell Biol 2013;14:83-97.

123 Bae HR, Kim DH, Park MH, Lee B, Kim MJ, Lee EK, et al: $\beta$-Hydroxybutyrate suppresses inflammasome formation by ameliorating endoplasmic reticulum stress via AMPK activation. Oncotarget 2016;7:66444-66454.

124 Shimazu T, Hirschey MD, Newman J, He W, Shirakawa K, Le Moan N, et al: Suppression of oxidative stress by $\beta$-hydroxybutyrate, an endogenous histone deacetylase inhibitor. Science 2013;339:211-214.

125 Nagao M, Toh R, Irino Y, Mori T, Nakajima H, Hara $\mathrm{T}$, et al: Hydroxybutyrate elevation as a compensatory response against oxidative stress in cardiomyocytes. Biochem Biophys Res Commun 2016;475:322-328.

126 Sweeney R, Wilbert J, Menge M, Gibson A, Klement R: PO-0688: implementation of a breast-hold lung gating system for left-sided breast cancer; hurdles and benefits. Radiother Oncol 2015;115:S336-S337.

127 Woolf EC, Rossi AP, Silva-Nichols HB, Gardner KD, Syed N, Scheck AC: Abstract 1125A: $\beta$-Hydroxybutyrate inhibits histone deacetylase activity and radiosensitizes malignant glioma cells. Cancer Res 2017;77:7445.

128 Veech RL, Bradshaw PC, Clarke K, Curtis W, Pawlosky R, King MT: Ketone bodies mimic the life span extending properties of caloric restriction. IUBMB Life 2017;69:305-314

129 Puchalska P, Crawford PA: Multi-dimensional roles of ketone bodies in fuel metabolism, signaling, and therapeutics. Cell Metab 2017;25:262-284.

130 Safdie FM, Dorff T, Quinn D, Fontana L, Wei M, Lee C, et al: Fasting and cancer treatment in humans: a case series report. Aging (Albany NY) 2009;1:988-1007.

131 de Groot S, Vreeswijk MP, Welters MJ, Gravesteijn G, Boei JJ, Jochems A, et al: The effects of short-term fasting on tolerance to (neo)adjuvant chemotherapy in HER2-negative breast cancer patients: a randomized pilot study. BMC Cancer 2015;15:652.
132 Dorff TB, Groshen S, Garcia A, Shah M, Tsao-Wei D, Pham H, et al: Safety and feasibility of fasting in combination with platinum-based chemotherapy. BMC Cancer 2016;16:360.

133 Raffaghello L, Safdie F, Bianchi G, Dorff T, Fontana L, Longo VD: Fasting and differential chemotherapy protection in patients. Cell Cycle 2010;9:4474-4476.

134 Klement RJ: Fasten als therapeutische Ergänzung. InFo Onkol 2016;19:14-16.

135 Klement RJ: Fasten als Ergänzung zur Chemotherapie. Gynakol Geburtshilfe 2016;21:9.

136 Klement RJ: Fasten als Nebenwirkungsmanagement? InFo Onkol 2016;19:22-24.

137 Pitter KL, Tamagno I, Alikhanyan K, Hosni-Ahmed A, Pattwell SS, Donnola S, et al: Corticosteroids compromise survival in glioblastoma. Brain 2016;139:1458-1471.

138 Klement RJ, Champ CE: Corticosteroids compromise survival in glioblastoma in part through their elevation of blood glucose levels. Brain 2017;140:e16

139 Champ CE, Palmer JD, Volek JS, Werner-Wasik M, Andrews DW, Evans JJ, et al: Targeting metabolism with a ketogenic diet during the treatment of glioblastoma multiforme. J Neurooncol 2014;117:125-131.

140 Klement RJ, Kämmerer U: Can a low carbohydrate ketogenic diet retard tumor growth? Aktuel Ernahrungsmed 2016;41:95-102.

141 Huisman SA, Bijman-Lagcher W, Ijzermans JNM, Smits R, de Bruin RWF: Fasting protects against the side effects of irinotecan but preserves its anti-tumor effect in Apc15lox mutant mice. Cell Cycle 2015;14:2333-2339.

142 Huisman SA, de Bruijn P, Ghobadi Moghaddam-Helmantel IM, IJzermans JNM, Wiemer EAC, Mathijssen RHJ, et al: Fasting protects against the side effects of irinotecan treatment but does not affect anti-tumour activity in mice. Br J Pharmacol 2016;173:804-814. 